\title{
Analysis of Aspects of Scientific Literacy on Anatomy and Physiology of the Human Body Textbooks University in Medan City
}

\author{
Rahmad Gultom ${ }^{1}$, Martina Restuati², Tumiur Gultom ${ }^{3}$ \\ ${ }^{1,2,3}$ Postgraduate School, Medan State University, Medan, Indonesia 20221 \\ *Corresponding author. Email: rahmadgultom24@gmail.com
}

\begin{abstract}
This study aims to analyze textbooks because most of the lecturers use textbooks as a learning guide in the classroom. The analysis carried out leads to an analysis of textbooks on scientific literacy, namely to find out the scope of scientific literacy in textbooks. This research is a descriptive study that aims to explain the scope of scientific literacy contained in the textbooks used in three campuses in the city of Medan, namely Medan State University, Imelda University and UIN SU. The population of this research is the whole material of Anatomy and Physiology of the Human Body. The sample of this research is wrong one of the most difficult to understand material, namely the regulatory system. Samples were taken by purposive sampling technique. The textbooks analyzed were 3 books of which the three books were used in each university. The data was taken using an observation sheet containing scientific literacy indicators, which were then translated into percentages for each book and indicator. The results of the research analysis show that the 1 aspects of scientific literacy as much as $45 \%, 2$ aspects as much as $28 \%, 3$ aspects as much as $31.66 \%$ and 4 aspects as much as $3.33 \%$. The study concluded that the three textbooks used in each of the colleges more emphasis on the presentation of facts, concepts, principles, laws, theories and models as well as emphasizing the Most students are able to recall the information through questions
\end{abstract}

Keywords: Science Literacy, Textbooks, Anatomy and Physiology of the Human Body, Content, Context, Process.

\section{INTRODUCTION}

The development of science and technology today in people's lives, requires humans to work harder to adapt in all aspects of life. One of them is the aspect of education that determines the progress and retreat of a nation's life in the midst of intense competition in the current era of globalization. [12] Liliasari (2011) tates that science education produces quality students who are shown to be aware of science ( scientific literacy), have values and high-level thinking skills which will later lead to human resources who can think critically, think creatively, make decisions and solve problems.

Scientific literacy according to [14] the Organization for Economic Cooperation and Development (OECD) (2013) is defined as the ability to use scientific knowledge, identify questions and draw conclusions based on facts to understand the universe and make decisions from changes that occur due to human activities. Scientific literacy is important for someone to have. Someone who has scientific literacy is a person who is able to use scientific concepts, has scientific process skills to make decisions related to everyday life, other people, society and the environment, including social and economic development [2] Arohman, 2016. Scientific literacy in Indonesia was introduced in 1993 with Indonesia complying with Unesco's invitation to participate in the International Forum on Science and Technological Literacy for All in Paris. Scientific literacy has begun to be applied in Indonesia through the KTSP curriculum and is more clearly visible in the 2013 curriculum through inquiry activities and scientific approaches [3] Astuti et al, 2015. The results of the PISA (Program for International Student Assessment) study in 2012 the average value of the scientific literacy component of Indonesian children was 382, which was below the ability scale which put Indonesia in 63rd rank out of 64 countries below Thailand which had an average 
score of 382. 444 took 50th place. In 2015 the average value was 403 Indonesia's ranking 69 of 76 countries was still below Thailand with a score of 421 with a rank of 60. This shows that Indonesia is still low in terms of scientific literacy and is still below the average of 493 . PISA is an international assessment program developed and followed by participating countries, and held for children aged 15 years. once every 3 years.

The results of these achievements reveal that the average science ability of Indonesian students is only able to recognize basic facts, they have not been able to communicate and relate these abilities to various science topics, let alone to apply concepts. Many factors can cause the low scientific literacy skills of students in Indonesia, including: 1) the applied education system; 2) applied models, approaches, methods, learning strategies ;3) the learning resources used; 4) student learning styles ; and 5) learning infrastructure. One of the factors mentioned above, which can cause a student's low scientific literacy ability is the learning resources used, such as textbooks or other learning resources. Therefore, to support the learning process and quality learning outcomes, excellent learning resources are needed and contain learning objectives according to the ongoing curriculum. Mastery of scientific literacy is one of the things demanded by the current curriculum in Indonesia. [4] The National Education Standards Agency (BSNP) (2006), revealed that Natural Science (IPA) is not only the mastery of a collection of knowledge in the form of facts, concepts, or principles, but also a process of discovery, namely the process of finding systematically know about natural phenomena. Science education is expected to be a vehicle for students to learn about themselves and the natural environment, as well as prospects for further development in application in everyday life. Based on this description, science learning is not only focused on mastering science content, but must also involve mastering the context and process of science. Quality learning in accordance with the expected curriculum, supported by the existence of learning resources that contain curriculum objectives, one of which is mastery of scientific literacy both mastery of content, context, and science processes.

\section{METHOD}

This research is a descriptive study which aims to identify the categories of scientific literacy contained in the anatomy and physiology textbooks of the human body which are used as learning resources for nonunimed biology education students. The population in this study are all books of anatomy and physiology of the human body used in a lecturer 's high in the city of Medan. The textbooks that were analyzed were the three most frequently used textbooks in teaching and learning activities in the selected 3 colleges per lecturer. The sample in this study is the material of the nervous system, the sensory system and the endocrine system. The material of the nervous system, the sensory system and the endocrine system is difficult material. Samples were taken by simple random sampling technique. The research instrument used was an analysis sheet containing indicators of scientific literacy categories adopted from [6] Chiappetta et al (1991b) in their journal entitled Do Middle School Life Science Textbooks Provide a Balance of Scientific Literacy Themes.

Data collection techniques are taken through the following steps:

1. Initial Stage: The initial stage in this research is conducting a literature study on scientific literacy and textbooks as well as compiling an indicator instrument for the scientific literacy category that will be used to analyze textbooks.

2. Implementation Stage:

a) Population Determination Stage

1) Conduct a survey of textbooks used by high school lecturers in Medan City . The survey was conducted at three per lecturer 's other high antata Unimed, Universitas Imelda and UIN SUMUT

2) Determining the third textbook per high school lecturer is often used as a learning resource in class.

b) Sampling Stage

1) Conduct a survey of the material in the textbook that is considered difficult by students

2) Among some materials, the nervous system, the sensory system and the endocrine system are considered to be one of the difficult materials

3) Making indicators from material on the nervous system, sensory system and endocrine system, which later on each indicator will be analyzed for its presence in the three textbooks.

3. Final Stage:

a) Analyze the indicators of the scientific literacy category on the material indicators of the nervous system, sensory system and endocrine system in textbook A, textbook B, and textbook C.

b) Processing and analyzing data by calculating the number and percentage of occurrences of scientific literacy category indicators on material indicators of the nervous system, sensory system and endocrine system in each textbook.

Data processing and analysis techniques carried out in this study are as follows: 
1. Summing up the appearance of the statements of each scientific literacy indicator in each of the material indicators of the nervous system, sensory system and endocrine system in the textbook.

2. Calculate the percentage of occurrences of the scientific literacy category in each analyzed textbook.

3. Determine the average percentage composition of each category of scientific literacy from the analyzed textbooks.

4. Provide descriptive analysis on each textbook that is analyzed based on the analytical data that has been processed.

\section{RESULTS AND DISCUSSION}

Based on the results of data analysis that has been carried out, the percentage of occurrences of scientific literacy category indicators for each material indicator of the nervous system, sensory system and endocrine system is obtained in the anatomy and physiology textbooks analyzed. Each textbook has a different percentage of scientific literacy categories. In the first indicator category of scientific literacy, namely science as a body of knowledge, textbook $\mathrm{A}$ has a total percentage of $50 \%$ of the 20 material indicators of the nervous system, sensory system and endocrine system. In the second category of scientific literacy indicators, namely science as a way of investigating, textbook B has a total percentage of $25 \%$ of the 11 material indicators of the nervous system, sensory system and endocrine system. The percentages obtained from the third and fourth indicator categories of scientific literacy, namely science as a way of thinking ( a way of thinking ) and the interaction of science, technology and society ( interaction of science, technology and society ) are $35 \%$ and $0 \%$ of the 20 indicators, respectively. material on the nervous system, sensory system and endocrine system textbook A. The following will be explained through Table 1.

From Table 1, note that of the four categories of indicators of scientific literacy, the category that most banya $\mathrm{k}$ emergence in the indicator material nervous system, sensory system and the endocrine system textbook A is the first indicator of scientific literacy, as much as $50 \%$, followed by the second indicator, the third and fourth scientific literacy are $25 \%, 35 \%$ and $0 \%$ respectively. The four material indicators of the nervous system, sensory system and endocrine system in textbook A are confirmed to meet the first indicator category of scientific literacy, namely science as a body of knowledge which includes: 1) presenting facts, concepts, principles principles and laws; 2) presenting hypotheses, theories and models; and 3) asking students to remember knowledge or information. Two indicators of material nervous system, sensory system and the endocrine system in the textbook A certainly meet the indicator the second scientific literacy, ie science as a way of investigating (the way of Investigating) which includes: 1) requires students to answer questions through the use of the material; 2) require students to answer questions through the use of graphs, tables etc.; 3) require students to make calculations; 4) requires students to explain answers; and 5) involving students in experimental activities or thinking activities. The third category of scientific literacy indicators, namely science as a way of thinking, appears only in one material indicator of the nervous system, sensory system and endocrine system. This explains that textbook A has a purpose so that students can think about conducting experiments, showing the development of an idea, providing causal relationships, discussing facts and evidence, and presenting scientific methods and problem solving.

The fourth category of scientific literacy, ie the interaction of science, technology with society (interaction of science, technology, and society), does not appear in the indicator material nervous system, sensory system and the endocrine system textbook A. This explains that in the material on the nervous system, sensory system and endocrine system, textbook A does not display everything related to science and technology in everyday life.

Category indicator first scientific literacy in a book teaching B , ie science as a body of knowledge (a body of knowledge), have a percentage as much as $45 \%$ of the 20 indicators of material nervous system, sensory system and endocrine system are presented. The second indicator category of scientific literacy is science as a way of investigating (a way of investigating), textbook B has a total percentage of $30 \%$ of the 20 material indicators of the nervous system, sensory system and endocrine system. The percentages obtained from the third and fourth indicator categories of scientific literacy, namely science as a way of thinking (a way of thinking) and the interaction of science, technology and society (interaction of science, technology and society) are $45 \%$ and $10 \%$, respectively, of the 20 material indicators. nervous system, sensory system and endocrine system textbook B. The following will be explained through Table 2. 
Table 1. Percentage of Science Literacy Indicator Categories on Material Indicators Nervous system, sensory system and endocrine system Textbook A

\begin{tabular}{|c|c|c|c|c|c|c|c|c|c|}
\hline \multirow[t]{3}{*}{ No } & \multirow{3}{*}{$\begin{array}{l}\text { SUB-CPMK Material of Regulatory } \\
\text { System }\end{array}$} & \multicolumn{8}{|c|}{ Category of Scientific Literacy Indicators } \\
\hline & & \multicolumn{2}{|l|}{1} & \multicolumn{2}{|l|}{2} & \multicolumn{2}{|l|}{3} & \multicolumn{2}{|l|}{4} \\
\hline & & Yes & No & Yes & No & Yes & No & Yes & No \\
\hline 1 & $\begin{array}{l}\text { Able to describe the structure of nerve } \\
\text { cells }\end{array}$ & $\sqrt{ }$ & & $\sqrt{ }$ & & & $\sqrt{ }$ & & $\sqrt{ }$ \\
\hline 2 & Describe the function of nerves & $\sqrt{ }$ & & & $\sqrt{ }$ & $\sqrt{ }$ & & & $\sqrt{ }$ \\
\hline 3 & $\begin{array}{l}\text { Understand the structure of the spinal cord } \\
\text { and nerves and their functions }\end{array}$ & $\sqrt{ }$ & & & $\sqrt{ }$ & & $\sqrt{1}$ & & $\sqrt{ }$ \\
\hline 4 & $\begin{array}{l}\text { Explain the relationship between nerve } \\
\text { cells }\end{array}$ & $\sqrt{ }$ & & & $\sqrt{ }$ & & $\sqrt{ }$ & & $\sqrt{ }$ \\
\hline 5 & Illustrate the impulse travel scheme & $\sqrt{ }$ & & & $\sqrt{ }$ & $\sqrt{ }$ & & & $\sqrt{ }$ \\
\hline 6 & $\begin{array}{l}\text { Describe the anatomical structure of the } \\
\text { spinal cord }\end{array}$ & & $\sqrt{ }$ & $\sqrt{ }$ & & $\sqrt{ }$ & $\sqrt{ }$ & & $\sqrt{ }$ \\
\hline 7 & Describe the function of the spinal cord & $\sqrt{ }$ & $\sqrt{ }$ & & $\sqrt{ }$ & & $\sqrt{ }$ & & $\sqrt{ }$ \\
\hline 8 & $\begin{array}{l}\text { Understand the mechanism of action of } \\
\text { hormones }\end{array}$ & & $\sqrt{ }$ & $\sqrt{ }$ & $\sqrt{ }$ & $\sqrt{1}$ & & & $\sqrt{ }$ \\
\hline 9 & $\begin{array}{l}\text { Describe the anatomical structure of the } \\
\text { brain }\end{array}$ & & $\sqrt{ }$ & & $\sqrt{ }$ & & $\sqrt{ }$ & & $\sqrt{ }$ \\
\hline 10 & Explain brain function & $\sqrt{ }$ & & $\sqrt{ }$ & & & $\sqrt{ }$ & & $\sqrt{ }$ \\
\hline 20 & $\begin{array}{l}\text { Describe the schematic of the reflex } \\
\text { motion process }\end{array}$ & $\sqrt{ }$ & & & $\sqrt{ }$ & & $\sqrt{ }$ & & $\sqrt{ }$ \\
\hline 12 & $\begin{array}{l}\text { Explain how the autonomic nervous } \\
\text { system works }\end{array}$ & $\sqrt{ }$ & $\sqrt{ }$ & & $\sqrt{ }$ & $\sqrt{ }$ & $\sqrt{ }$ & & $\sqrt{ }$ \\
\hline 13 & $\begin{array}{l}\text { Explain the occurrence of disorders and } \\
\text { disorders of the nervous system }\end{array}$ & & $\sqrt{1}$ & & $\sqrt{ }$ & & $\sqrt{ }$ & & $\sqrt{ }$ \\
\hline 14 & $\begin{array}{l}\text { Describe the anatomical structure of each } \\
\text { sense tool }\end{array}$ & $\sqrt{ }$ & & & $\sqrt{ }$ & $\sqrt{1}$ & & & $\sqrt{ }$ \\
\hline 15 & Explain the function of each sense organ & $\sqrt{ }$ & & & $\sqrt{ }$ & & $\sqrt{ }$ & & $\sqrt{ }$ \\
\hline 16 & $\begin{array}{l}\text { Explain the mechanism of action of each } \\
\text { of the senses }\end{array}$ & & $\sqrt{ }$ & $\sqrt{ }$ & & & $\sqrt{ }$ & & $\sqrt{ }$ \\
\hline 17 & $\begin{array}{l}\text { Explain the occurrence of abnormalities } \\
\text { and disturbances in the senses }\end{array}$ & & $\sqrt{ }$ & $\sqrt{ }$ & & & $\sqrt{1}$ & & $\sqrt{ }$ \\
\hline 18 & $\begin{array}{l}\text { Mendi thesis about the anatomy and } \\
\text { physiology of the endocrine system in } \\
\text { humans }\end{array}$ & $\sqrt{ }$ & & & $\sqrt{ }$ & $\sqrt{ }$ & & & $\sqrt{ }$ \\
\hline 19 & Describe the types of hormone glands & & $\sqrt{ }$ & & $\sqrt{ }$ & & $\sqrt{ }$ & & $\sqrt{ }$ \\
\hline 20 & $\begin{array}{l}\text { Explain the influence of hormones in the } \\
\text { body's physiological processes }\end{array}$ & & $\sqrt{ }$ & $\sqrt{ }$ & $\sqrt{ }$ & & $\sqrt{ }$ & & $\sqrt{ }$ \\
\hline \multicolumn{2}{|r|}{ amount } & 10 & 10 & 5 & 15 & 7 & 13 & 0 & 20 \\
\hline \multicolumn{2}{|c|}{ percentage } & $50 \%$ & $50 \%$ & $25 \%$ & $75 \%$ & $35 \%$ & $65 \%$ & $0 \%$ & $100 \%$ \\
\hline
\end{tabular}


Table 2. Percentage of Science Literacy Indicator Categories on Material Indicators Nervous system, sensory system and endocrine system Textbook B

\begin{tabular}{|c|c|c|c|c|c|c|c|c|c|}
\hline \multirow[t]{3}{*}{ No } & \multirow{3}{*}{$\begin{array}{l}\text { SUB-CPMK Material of Regulatory } \\
\text { System }\end{array}$} & \multicolumn{8}{|c|}{ Category of Scientific Literacy Indicators } \\
\hline & & \multicolumn{2}{|l|}{1} & \multicolumn{2}{|l|}{2} & \multicolumn{2}{|l|}{3} & \multicolumn{2}{|l|}{4} \\
\hline & & Yes & No & Yes & No & Yes & No & Yes & No \\
\hline 1 & $\begin{array}{l}\text { Able to describe the structure of nerve } \\
\text { cells }\end{array}$ & & $\sqrt{ }$ & $\sqrt{ }$ & & & $\sqrt{ }$ & & $\sqrt{ }$ \\
\hline 2 & Describe the function of nerves & $\sqrt{ }$ & & & $\sqrt{ }$ & $\sqrt{ }$ & & & $\sqrt{ }$ \\
\hline 3 & $\begin{array}{l}\text { Understand the structure of the spinal } \\
\text { cord and nerves and their functions }\end{array}$ & $\sqrt{ }$ & & & $\sqrt{ }$ & & $\sqrt{ }$ & & $\sqrt{ }$ \\
\hline 4 & $\begin{array}{l}\text { Explain the relationship between nerve } \\
\text { cells }\end{array}$ & $\sqrt{ }$ & & & $\sqrt{1}$ & & $\sqrt{ }$ & & $\sqrt{ }$ \\
\hline 5 & Illustrate the impulse travel scheme & $\sqrt{ }$ & & & $\sqrt{ }$ & $\sqrt{ }$ & & & $\sqrt{ }$ \\
\hline 6 & $\begin{array}{l}\text { Describe the anatomical structure of the } \\
\text { spinal cord }\end{array}$ & $\sqrt{ }$ & & $\sqrt{ }$ & & $\sqrt{ }$ & $\sqrt{ }$ & & $\sqrt{ }$ \\
\hline 7 & Describe the function of the spinal cord & & $\sqrt{ }$ & & $\sqrt{ }$ & & $\sqrt{ }$ & & $\sqrt{ }$ \\
\hline 8 & $\begin{array}{l}\text { Understand the mechanism of action of } \\
\text { hormones }\end{array}$ & & $\sqrt{ }$ & $\sqrt{1}$ & $\sqrt{ }$ & $\sqrt{1}$ & & & $\sqrt{ }$ \\
\hline 9 & $\begin{array}{l}\text { Describe the anatomical structure of the } \\
\text { brain }\end{array}$ & & $\sqrt{ }$ & & $\sqrt{1}$ & & $\sqrt{ }$ & & $\sqrt{ }$ \\
\hline 10 & Describe brain function & $\sqrt{1}$ & & $\sqrt{ }$ & & & $\sqrt{ }$ & & $\sqrt{ }$ \\
\hline 11 & $\begin{array}{l}\text { Describe the schematic of the reflex } \\
\text { movement process }\end{array}$ & & $\sqrt{ }$ & & $\sqrt{ }$ & & $\sqrt{ }$ & & $\sqrt{ }$ \\
\hline 12 & $\begin{array}{l}\text { Explain how the autonomic nervous } \\
\text { system works }\end{array}$ & & $\sqrt{ }$ & & $\sqrt{ }$ & $\sqrt{1}$ & $\sqrt{1}$ & & $\sqrt{1}$ \\
\hline 13 & $\begin{array}{l}\text { Explain the occurrence of disorders and } \\
\text { disorders of the nervous system }\end{array}$ & & $\sqrt{ }$ & & $\sqrt{ }$ & & $\sqrt{ }$ & & $\sqrt{ }$ \\
\hline 14 & $\begin{array}{l}\text { Describe the anatomical structure of } \\
\text { each sense organ }\end{array}$ & $\sqrt{ }$ & & & $\sqrt{ }$ & $\sqrt{ }$ & & & $\sqrt{ }$ \\
\hline 15 & $\begin{array}{l}\text { Explain the function of each sense } \\
\text { organ }\end{array}$ & $\sqrt{ }$ & & & $\sqrt{1}$ & $\sqrt{ }$ & & $\sqrt{ }$ & \\
\hline 16 & $\begin{array}{l}\text { Explain the mechanism of action of } \\
\text { each of the senses }\end{array}$ & & $\sqrt{ }$ & $\sqrt{1}$ & & $\sqrt{1}$ & & $\sqrt{1}$ & \\
\hline 17 & $\begin{array}{l}\text { Explain the occurrence of abnormalities } \\
\text { and disturbances in the senses }\end{array}$ & & $\sqrt{ }$ & $\sqrt{ }$ & & & $\sqrt{ }$ & & $\sqrt{ }$ \\
\hline 18 & $\begin{array}{l}\text { Describe the anatomy and physiology } \\
\text { of the human endocrine system }\end{array}$ & $\sqrt{ }$ & & & $\sqrt{1}$ & $\sqrt{1}$ & & & $\sqrt{ }$ \\
\hline 19 & Describe the types of hormone glands & & $\sqrt{ }$ & $\sqrt{ }$ & & & $\sqrt{ }$ & & $\sqrt{ }$ \\
\hline 20 & $\begin{array}{l}\text { Explain the influence of hormones in } \\
\text { the body's physiological processes }\end{array}$ & & $\sqrt{ }$ & $\sqrt{ }$ & $\sqrt{ }$ & & $\sqrt{ }$ & & $\sqrt{ }$ \\
\hline \multicolumn{2}{|c|}{ amount } & 9 & 20 & 6 & 14 & 9 & 11 & 2 & 18 \\
\hline \multicolumn{2}{|c|}{ percentage } & $45 \%$ & $55 \%$ & $30 \%$ & $70 \%$ & $45 \%$ & $55 \%$ & $10 \%$ & $90 \%$ \\
\hline
\end{tabular}

Table 2 shows that the category of scientific literacy indicator that appears the most in the material indicators of the nervous system, sensory system and endocrine system of textbook $y$ is the first category of scientific literacy indicator as much as $45 \%$. The first category of scientific literacy indicators, namely science as the body of knowledge appears in the material indicators of the nervous system, sensory system and endocrine system which also has the aim of making students able to remember knowledge or information. The second and third categories of scientific literacy indicators have different frequency of occurrence in the material indicators of the nervous system, sensory system and 
endocrine system in textbook b, namely $30 \%$ and $45 \%$. The second and third categories of scientific literacy indicators appear in the material indicators of the nervous system, sensory system and endocrine system with the appear at all in the indicator material nervous system, sensory system and the endocrine system textbook c. Similar to textbook a, in the material on the nervous system, sensory system and endocrine system, textbook

Table 3. Percentage of Science Literacy Indicator Categories on Material Indicators Nervous system, sensory system and endocrine system $\mathrm{C}$ Textbook

\begin{tabular}{|c|c|c|c|c|c|c|c|c|c|}
\hline \multirow[t]{3}{*}{ No } & \multirow[t]{3}{*}{ SUB-CPMK Material of Regulatory System } & \multicolumn{8}{|c|}{ Category of Scientific Literacy Indicators } \\
\hline & & \multicolumn{2}{|l|}{1} & \multicolumn{2}{|l|}{2} & \multicolumn{2}{|l|}{3} & \multicolumn{2}{|l|}{4} \\
\hline & & Yes & No & Yes & No & Yes & No & Yes & No \\
\hline 1 & Able to describe the structure of nerve cells & & $\sqrt{ }$ & $\sqrt{ }$ & & & $\sqrt{ }$ & & $\sqrt{ }$ \\
\hline 2 & Describe the function of nerves & $\sqrt{ }$ & & & $\sqrt{ }$ & $\sqrt{ }$ & & & $\sqrt{ }$ \\
\hline 3 & $\begin{array}{l}\text { Understand the structure of the spinal cord and } \\
\text { nerves and their functions }\end{array}$ & & $\sqrt{ }$ & & $\sqrt{ }$ & & $\sqrt{ }$ & & $\sqrt{ }$ \\
\hline 4 & Explain the relationship between nerve cells & $\sqrt{ }$ & & & $\sqrt{ }$ & & $\sqrt{ }$ & & $\sqrt{ }$ \\
\hline 5 & Illustrate the impulse travel scheme & $\sqrt{ }$ & & & $\sqrt{ }$ & $\sqrt{ }$ & & & $\sqrt{ }$ \\
\hline 6 & Describe the anatomical structure of the spinal cord & & $\sqrt{ }$ & $\sqrt{ }$ & & $\sqrt{ }$ & & & $\sqrt{ }$ \\
\hline 7 & Describe the function of the spinal cord & & $\sqrt{ }$ & & $\sqrt{ }$ & & $\sqrt{ }$ & & $\sqrt{ }$ \\
\hline 8 & Understand the mechanism of action of hormones & & $\sqrt{ }$ & $\sqrt{ }$ & & $\sqrt{ }$ & & & $\sqrt{ }$ \\
\hline 9 & Describe the anatomical structure of the brain & & $\sqrt{ }$ & & $\sqrt{ }$ & & $\sqrt{ }$ & & $\sqrt{ }$ \\
\hline 10 & Men explain brain function & $\sqrt{ }$ & & $\sqrt{ }$ & & & $\sqrt{ }$ & & $\sqrt{ }$ \\
\hline 20 & $\begin{array}{l}\text { Describe the schematic of the reflex movement } \\
\text { process }\end{array}$ & $\sqrt{ }$ & & & $\sqrt{ }$ & & $\sqrt{ }$ & & $\sqrt{ }$ \\
\hline 12 & Explain how the autonomic nervous system works & & $\sqrt{ }$ & & $\sqrt{ }$ & $\sqrt{ }$ & & & $\sqrt{ }$ \\
\hline 13 & $\begin{array}{l}\text { Explain the occurrence of disorders and disorders } \\
\text { of the nervous system }\end{array}$ & & $\sqrt{ }$ & & $\sqrt{ }$ & & $\sqrt{ }$ & & $\sqrt{ }$ \\
\hline 14 & $\begin{array}{l}\text { Describe the anatomical structure of each sense } \\
\text { organ }\end{array}$ & $\sqrt{ }$ & & & $\sqrt{ }$ & $\sqrt{ }$ & & & $\sqrt{ }$ \\
\hline 15 & Explain the function of each sense organ & $\sqrt{ }$ & & & $\sqrt{ }$ & & $\sqrt{ }$ & & $\sqrt{ }$ \\
\hline 16 & $\begin{array}{l}\text { Explain the mechanism of action of each of the } \\
\text { senses }\end{array}$ & & $\sqrt{ }$ & $\sqrt{ }$ & & & $\sqrt{ }$ & & $\sqrt{ }$ \\
\hline 17 & $\begin{array}{l}\text { Explain the occurrence of abnormalities and } \\
\text { disturbances in the senses }\end{array}$ & & $\sqrt{ }$ & $\sqrt{ }$ & & & $\sqrt{ }$ & & $\sqrt{ }$ \\
\hline 18 & $\begin{array}{l}\text { Describe the anatomy and physiology of the human } \\
\text { endocrine system }\end{array}$ & $\sqrt{ }$ & & & $\sqrt{ }$ & & $\sqrt{ }$ & & $\sqrt{ }$ \\
\hline 19 & Describe the types of hormone glands & & $\sqrt{ }$ & $\sqrt{ }$ & & & $\sqrt{ }$ & & $\sqrt{ }$ \\
\hline 20 & $\begin{array}{l}\text { Explain the influence of hormones in the body's } \\
\text { physiological processes }\end{array}$ & & $\sqrt{ }$ & $\sqrt{ }$ & & & $\sqrt{ }$ & & $\sqrt{ }$ \\
\hline \multicolumn{2}{|c|}{ amount } & 8 & 12 & 8 & 12 & 6 & 14 & 0 & 20 \\
\hline \multicolumn{2}{|c|}{ percentage } & $\begin{array}{l}40 \\
\%\end{array}$ & $\begin{array}{l}60 \\
\%\end{array}$ & $\begin{array}{l}40 \\
\%\end{array}$ & $\begin{array}{l}60 \\
\%\end{array}$ & $\begin{array}{l}30 \\
\%\end{array}$ & $65 \%$ & $0 \%$ & $\begin{array}{l}100 \\
\%\end{array}$ \\
\hline
\end{tabular}

aim that students are able to answer questions and make calculations through the use of materials and graphs. The fourth category of indicators of scientific literacy, ie the interaction of science, technology with society (interaction of science, technology, and society) does not a does not display everything related to science and technology in everyday life.

Science as a body of knowledge is the first indicator category of scientific literacy in textbook $\mathrm{C}$, having a percentage of $36.36 \%$ of the 11 material indicators of the 
nervous system, sensory system and endocrine system presented. The second and third indicator categories of scientific literacy, namely science as a way of investigating ( a way of investigating ) and science as a way of thinking ( a way of thinking ) in $\mathrm{Z}$ textbooks have the same total percentage, which is $27.27 \%$ of the 11 system material indicators. nervous, sensory and endocrine systems. The percentage obtained from the fourth indicator category of scientific literacy, namely the interaction of science, technology and society (interaction of science, technology and society) has a percentage of $9.09 \%$ of the 11 material indicators of the nervous system, sensory system and endocrine system of textbook Z. The following will be explained through Table 3.

The percentage of the first category of scientific literacy, ie science as a body of knowledge (a body of knowledge) material nervous system, sensory system and endo system Krin textbook C by $40 \%$. Of the 20 material indicators of the nervous system, sensory system and endocrine system of textbook $\mathrm{C}$ presented, four indicators that have the first emergence of the scientific literacy category are confirmed to present facts, concepts, principles, laws and theories. In addition, the four material indicators of the nervous system, sensory system and endocrine system of textbook $\mathrm{C}$ also aim to make students remember the information contained in the four material indicators of the nervous system, sensory system and endocrine system. The first category of scientific literacy indicators is the indicator category that appears the most among the 20 material indicators of the nervous system, sensory system and endocrine system of textbook $\mathrm{C}$ presented. The second and third categories of scientific literacy indicators, namely science as a way of investigating (way of investigating) and science as a way of thinking (way of thinking), have the same percentage frequency of occurrence, which is $40 \%$. The second and third categories of scientific literacy indicators appear in the same material indicators of the nervous system, sensory system and endocrine system in textbook $\mathrm{C}$. This indicates that textbook $\mathrm{C}$ is still unable to form students to develop an idea from providing facts or evidence. The fourth category of scientific literacy indicators, namely the interaction of science, technology and society (interaction of science, technology, and society) did not appear. This indicates that in the material on the nervous system, sensory system and endocrine system, textbook $\mathrm{C}$ does not display everything related to science and technology in everyday life. In fact, if the category of scientific literacy indicators is reproduced, learning will take place more interestingly and students will be enthusiastic in learning.

The dimension of science content is indeed needed to be the foundation for students to know the basis of the knowledge being studied. The first category of scientific literacy indicators, namely science as a body of knowledge that appears the most in textbooks A, B, and
$\mathrm{C}$ is a statement that presents facts, concepts, principles, laws. The statements presented are more directed to the theory that must be memorized by students. The presentation of facts, concepts, principles, and laws is indeed important given to students as a foundation in learning a science, but if the gift is too excessive it will result in students becoming less interested in learning. Presentation of material on the nervous system, sensory system and endocrine system that is too dominant for memorization actually causes students to feel less interested and get bored more quickly. It would be better if textbooks provide keywords in an interesting way, which can be constructed by students themselves, so that students feel challenged to follow the learning path of the nervous system, sensory system and endocrine system more deeply. Another category of scientific literacy indicators, namely, science as a way to investigate and science as a way of thinking has a not too high percentage in textbooks A, B, and C. This is evidenced by the fact that students who use textbooks $\mathrm{A}, \mathrm{B}$, and $\mathrm{C}$ and $\mathrm{C}$ can answer the questions given by the lecturer by using the answers they have memorized, rather than developing the knowledge they have. The activity of thinking in answering questions given by the lecturer is only by copying the answers that have been memorized by students. Students are less able to develop the knowledge they already have to find more appropriate answers. The third and fourth categories of scientific literacy indicators, namely science as a way to investigate and science as a way of thinking are included in the dimensions of the scientific process. The scientific process dimension refers to the mental processes involved when students answer a question or solve a problem, such as identifying and interpreting evidence, and explaining conclusions. The second and third categories of scientific literacy indicators appear quite a lot in the material indicators of the nervous system, sensory system and endocrine system textbooks A, B , and $\mathrm{C}$, although they do not appear as much as the first category of scientific literacy indicators. With this, in addition to present scientific knowledge, textbook A, B, and $\mathrm{C}$ are also capable of developing science process skills of students which includes the ability to think and investigate in the field of science. Statements that often appear on the dimensions of the process of science in textbooks A, B , and C among other scientific methods and problem solving that can train the way of thinking of students to be able to link cause and effect, to discuss the facts and evidence, conduct experiments, explain the answers and make calculations. Students can observe the patterns used to solve problems of anatomy and physiology of the human body or other problems related to science in everyday life. The fourth category of scientific literacy indicators, namely the interaction of science, technology with society, has a low percentage of appearances in the material indicators of the nervous system, sensory system and endocrine system of textbooks A, B, and C. 
In theory, there is no standard provision that regulates the scope of the scientific literacy indicator category in science textbooks. However, if the composition of the presentation of the scientific knowledge indicator category (scientific content) is more dominant than other scientific literacy indicator categories, it is feared that students will be less developed in building their own knowledge and conducting investigations into scientific phenomena. Therefore, it is important to develop quality teaching materials for anatomy and physiology of the human body to improve students' scientific literacy skills that include the dimensions of content, process and context. With the existence of quality teaching materials, not only students' scientific literacy skills will increase, but students ' motivation and enthusiasm for learning about the subjects of anatomy and physiology of the human body will also increase.

\section{CONCLUSION}

There are four categories of scientific literacy that will be analyzed in eleven indicators of material nervous system, sensory system and the endocrine system that is science as a body of knowledge (a body of knowledge), science as a way to investigate (the way of Investigating), science as a way of thinking (the way of thinking), and the interaction of science, technology and society (interaction of science, technology, and society). The scientific literacy indicator category that appears the most in textbooks A, B , and C is the first indicator category, namely science as the body of knowledge, with the respective percentages of $50 \%, 45 \%$, and $40 \%$. Category indicators of scientific literacy appears the second and third bit in the textbook A, B, and C. While the category of scientific literacy that fourth indicator does not appear in the textbook $\mathrm{A}$ and $\mathrm{C}$, and little appears in the textbook Breakfast. This proves that textbooks A, B, and $\mathrm{C}$ have not been able to accommodate all dimensions of scientific literacy, namely the dimensions of content, process and context. Although the content dimension has the highest percentage of material indicators of the nervous system, sensory system and endocrine system, it does not fulfill all the material indicators of the nervous system, sensory system and endocrine system presented. The process and context dimensions of textbooks $\mathrm{A}, \mathrm{B}$, and $\mathrm{C}$ need to be improved in presentation so that students have good skills in understanding the interaction of science and technology with society.

\section{REFERENCES}

[1] Adisendjaja, YH (2009). Analysis of Class X Biology Textbooks in Bandung City Based on Scientific Literacy . Department of Biology Education FPMIPA UPI. Bandung: Unpublished.

[2] Arohman, M., Saefudin., \& Priyandoko, D. (2016). Students' Science Literacy Ability in Ecosystem
Learning . Proceedings of Biology Education Conference , 13(1), 90-92.

[3] Astuti, R., Sunarno, W., \& \& Sudarisman, S. (2015). Science Learning With Approach to Science Process Skills Using Experimental Methods Free Modified And Guided Experiment. Seminar Proceedings National Science Education (SNPS) 2015 (pp. 173-184). Surakarta: Sebelas Maret University, Surakarta.

[4] BSNP. (2006). The Minister of National Education of the Republic of Indonesia No. 22 of 2006 concerning Content Standards for Primary and Secondary Education Units . Jakarta.

[5] Campbell NA, JB Reece, LA Urry, ML Cain, SA Waserman, PV Minorsky \& RB Jackson. (2010). Biology Eighth Edition Volume 2 . Jakarta: PT. Erlangga

[6] Chiappetta, EL, Fillman, DA, and Sethna, GH (1991b). A Quantitative Analysis of High School Chemistry Textbooks for Scientific Literacy Themes and Expository Learning Aids. Journal of research in science teaching . 28(10), 939-951.

[7] Chiappetta, EL, Fillman, DA, and Sethna, GH (1993). Do Middle School Life Science Textbooks Provide a Balance of Scientific Literacy Themes?. Journal of research in science teaching . 30(2), 787 $-797$.

[8] Chiappetta, EL, Fillman, DA, and Sethna, GH (1991a). A Method to Quantify Major Themes of Scientific Literacy in Science Textbooks. Journal of research in science teaching . 28(8), 713-725.

[9] Firman, H. (2007). Analysis of Scientific Literacy Based on the 2006 National PISA Results . Jakarta: Center for Educational Assessment, Research and Development of the Ministry of National Education.

[10] Hartika, D. (2016). Student Science Literacy Competency Profile Based on Program For International Student Assessment (PISA) on Biological Content . Faculty of Teacher Training and Education, University of Lampung.

[11] Husna, Rifnatul. , Hasruddin, \& Syarifuddin. (2013). Development of Problem-Based Applied Microbiology Research Minibook . Proceedings of the Biology Education Conference. ISNN 25285742. Vol 10, No 1 (2013)

[12] Liliasari. (2011). Building a Science Literate Society with National Character Through Learning - SPsUPI Science Education Study Program . Bandung: Unpublished. Sandi, MI, Setiawan, A., \& Rusnayati, H. (2014). Analysis of Class X High School Physics Textbooks in Bandung City Based 
on Science Literacy Components . Indonesian University of Education (UPI). Bandung: Unpublished.

[13] Nur, M. 1995. Understanding of Science and Science Process Skills for Biology, Physics and Chemistry Department Students, FPMIPA IKIP . Doctoral dissertation . Bandung: SPS IKIP.

[14] OECD. (2015). Chapter 3 of the Publication "PISA 2015 Assessment of framework - mathematics, Reading, Science and problem solving knowledge and skills. [Online] . 